\title{
Mechanical properties and deformation behaviour of laminated titanium-intermetallic composites synthesised using $\mathrm{Ti}$ and $\mathrm{Cu}$ foils
}

\author{
M. Konieczny* \\ Kielce University of Technology, Department of Metals Science and Materials Technologies, \\ Al. 1000-lecia P. P. 7, Kielce 25-314, Poland
}

Received 10 February 2009, received in revised form 26 October 2009, accepted 26 October 2009

\begin{abstract}
Ti-intermetallic laminated composites were fabricated via reaction synthesis in vacuum using foils of titanium and copper with controlled temperature, treating time and pressure. Microstructural examinations using SEM and EDX demonstrated that copper layers were completely consumed and five intermetallic compounds: $\mathrm{Ti}_{2} \mathrm{Cu}, \mathrm{TiCu}$ (predominant phase), $\mathrm{Ti}_{3} \mathrm{Cu}_{4}, \mathrm{Ti}_{2} \mathrm{Cu}_{3}$ and $\mathrm{TiCu}_{4}$ were formed. The mechanical properties and fracture behaviour of the fabricated composites were examined. The results showed that treating time at $900{ }^{\circ} \mathrm{C}$ was a main factor determining properties. After 5 hours of treating all investigated composites with the same thickness of starting Ti foil have higher yield strength, higher ultimate tensile strength and higher flexural strength than composites after 0.5 hour of treating. Only strain at fracture of the composites decreases with increasing of the treating time. The composites exhibited good cohesion between layers during tensile test. Delamination of layers occurred during three-point bending test, especially when the load perpendicular to the laminates was applied.
\end{abstract}

K e y w or d s: laminated composite, intermetallics, mechanical properties, delamination

\section{Introduction}

Laminated structures are being intensively studied for a number of potential applications: structural components, armour, electronic devices, etc. Presently, there is a great interest in metal-intermetallic laminated (MIL) composites since they can perform various functions, such as: blast mitigation, ballistic protection, vibration damping, and heat exchange [1]. Among many laminate composites, the Ni-AlNi laminate has high potential for substituting Ni-based superalloys [2] and the $\mathrm{Ti} 6 \mathrm{Al} 4 \mathrm{~V}-\mathrm{Al}_{3} \mathrm{Ti}$ laminate attracts special attention for aerospace applications [3]. MIL composites can be fabricated via many different techniques: diffusion bonding [4], magnetron sputtering [5], electron beam evaporation [6], vacuum plasma spraying [7], and synthesis reactions between dissimilar elemental metal foils [2, 3, 8-23]. Reaction synthesis using foils has some advantages over other methods. The obvious economic benefit lies in the ease of processing. To obtain a composite, foils of one metal are placed alternately with thicker foils of another metal into a packet. The packet is heated to a temperature that starts the reaction between the metals. The process is continued till one of the metals is fully consumed in the course of reaction. Because the products of the synthesis are growing into a layer, finally a metal-intermetallic laminated composite is obtained. The multilayered structure of the composite allows for variations in the layer thickness and phase volume fractions of the components simply through the selection of initial foil thickness, which consequently allows for the optimisation of mechanical properties for practical applications. It is also worth mentioning that the size and the number of layers of the component that can be produced are not limited. Furthermore, the process uses readily available elemental foils, which can easily be shaped

* Tel.: 00480413424 522; fax: 00480413448 698; e-mail address: mkon@interia.pl 
Table 1. Chemical composition and tensile properties of the base materials

\begin{tabular}{|c|c|c|c|}
\hline Material & \multicolumn{3}{|c|}{ Chemical composition (wt.\%) } \\
\hline CP Ti (Grade 1) & \multicolumn{3}{|c|}{ Ti: 99.5, Fe: 0.09, C: 0.08, Al: 0.13, O: $0.18, \mathrm{~N}: 0.02$} \\
\hline \multirow[t]{3}{*}{ Cu99.99 } & \multicolumn{3}{|c|}{ Cu: 99.99, Fe: 0.001, Ni: 0.001, Zn: 0.001, Sn: 0.001, Pb: 0.001, Sb: 0.001, As: 0.001, S: 0.001} \\
\hline & \multicolumn{3}{|c|}{ Tensile properties } \\
\hline & Offset yield strength $(\mathrm{MPa})$ & Ultimate tensile strength $(\mathrm{MPa})$ & Fracture elongation (\%) \\
\hline $\mathrm{CP} \mathrm{Ti}$ & 198 & 242 & 24 \\
\hline Cu99.99 & 68 & 219 & 45 \\
\hline
\end{tabular}

prior to the initiation of the synthesis reaction, resulting in the potential to produce near-net-shaped composites [8]. A number of laminates have been produced in the way of intermetallic compounds synthesis using foils: $\mathrm{Ni}$ and $\mathrm{Al}[2,8-10]$, $\mathrm{Fe}$ and $\mathrm{Al}$ [11], $\mathrm{Nb}$ and $\mathrm{Al}$ [12-14], $\mathrm{Ti}$ and $\mathrm{Al}$ [15-17], Ti6Al4V and $\mathrm{Al}[3,18]$, or $\mathrm{Ti}$ and $\mathrm{Cu}[19]$. An extensive work on the strain failure mechanism in a large range of metal-intermetallic layered composites was conducted in the early 1990's in a series of studies carried out at the U.S. Department of Energy [8, 21, 22]. Previous works were devoted mainly to the mechanism of damage evolution and fracture behaviour of the metal-aluminide $[3,12-14,16]$ and $\mathrm{Cu}$-titanide $[22,23]$ composites. The aim of this work was to study mechanical properties and deformation behaviour of the Ti-intermetallic laminated composites formed through in-situ reactions between $\mathrm{Ti}$ and $\mathrm{Cu}$ foils.

\section{Experimental procedure}

In the experiment, $0.15,0.20$ and $0.25 \mathrm{~mm}$ thick foils of titanium and $0.05 \mathrm{~mm}$ thick foil of copper were used to fabricate laminated titanium-intermetallic composites with controlled temperature, treating time and pressure. The chemical compositions and tensile properties of the base materials are given in Table 1 .

Titanium and copper foils were cut into $50 \mathrm{~mm} \times$ $10 \mathrm{~mm}$ rectangular pieces and ground with 800-grit abrasive paper. Rinsed first with water and then with ethanol and next dried rapidly, the foils were placed alternately to form titanium/copper/titanium multilayer packets (11 $\mathrm{Ti}$ and $10 \mathrm{Cu}$ layers). The packets were then treated in a furnace under vacuum of $10^{-4} \mathrm{~Pa}$. A pressure of $5 \mathrm{MPa}$ was applied at room temperature to ensure good contact and diffusion bonding between the foils. The temperature was initially raised to $850^{\circ} \mathrm{C}$ and the heating time at this temperature was 0.5 hour. After that the foils were heated to $900{ }^{\circ} \mathrm{C}$ and held at this tem- perature for 0.5 and 5 hours. No pressure was applied to the specimen during this sequence of process with the purpose of eliminating expulsion of liquid phases. The temperature was then decreased slowly to $800^{\circ} \mathrm{C}$ and the pressure of $5 \mathrm{MPa}$ was applied again. The thermal ageing cycle at $800^{\circ} \mathrm{C}$ was employed for 0.5 hour to remove any residual porosity and to close cracks that might have formed as a result of shrinkage during solidification of the transient liquid phase. Finally, the sample was furnace-cooled to room temperature (cooling rate of $0.16^{\circ} \mathrm{Cs}^{-1}$ ). After fabrication, the specimens were cut, mounted in a cold setting resin, mechanically ground initially with a grade 800 abrasive paper and finally polished using Struers polishing machine and $1 \mu \mathrm{m}$ diamond suspension. Microstructural observations were performed using a JEOL JMS 5400 scanning electron microscope and a Carl Zeiss NEOPHOT 2 optical microscope. The chemical composition of the phases was determined by an energy dispersive spectroscopy using ISIS 300 Oxford Instruments. Before the samples were examined with the optical microscope they had been etched using an aqueous HF solution $(2 \%)$ to reveal any titanium grain boundaries and the structure of the intermetallic layers. Vickers measurements were conducted using a Hanemann microhardness tester mounted on NEOPHOT 2 microscope under load of $0.637 \mathrm{~N}$ for $15 \mathrm{~s}$. Samples with dimensions of $50 \mathrm{~mm} \times 8 \mathrm{~mm} \times 3 \mathrm{~mm}$, made from fabricated composites, were subjected to tension test on an INSTRON screw machine at a constant crosshead speed of $0.1 \mathrm{~mm} \mathrm{~min}^{-1}$, corresponding to an initial strain rate of $1.68 \times 10^{-3} \mathrm{~s}^{-1}$. The flexural strength measurements were performed using a three-point bending test on the specimens with dimensions of $36 \mathrm{~mm} \times 4 \mathrm{~mm} \times 3 \mathrm{~mm}$, where the loading span was $30 \mathrm{~mm}$. Two loading directions were used: one perpendicular and another parallel to the laminates. The tests were carried out under displacement control at a rate of $8.3 \times 10^{-3} \mathrm{~mm} \mathrm{~s}^{-1}\left(0.5 \mathrm{~mm} \mathrm{~min}^{-1}\right)$. The crack propagation traces and fracture surfaces were examined using Nomarski contrast. 


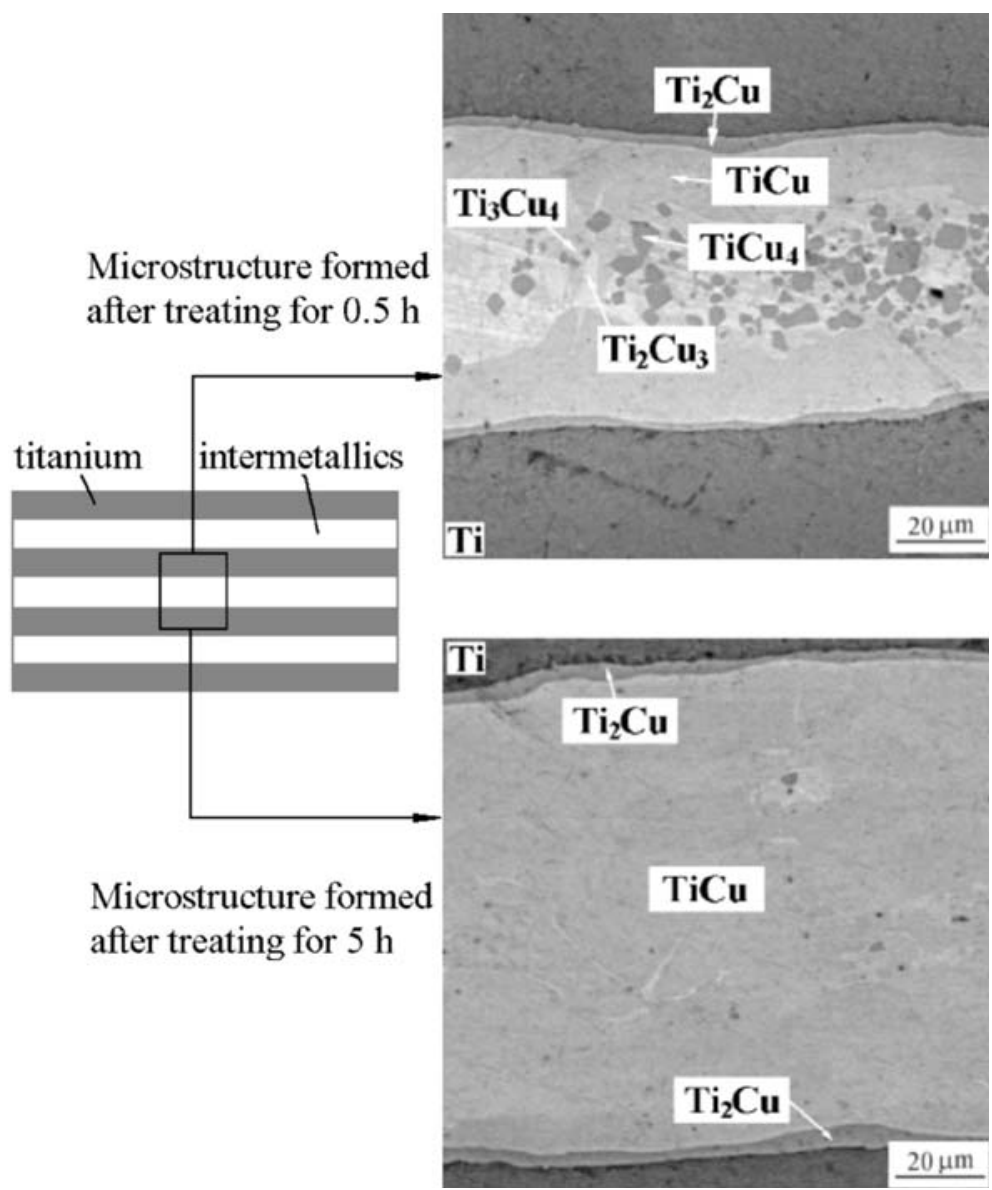

Fig. 1. Microstructures of the intermetallic layers in composites treated at $900^{\circ} \mathrm{C}$ for 0.5 and 5 hours.

Ta ble 2. Summary of microstructures of investigated composites

\begin{tabular}{|c|c|c|c|c|c|}
\hline \multirow{2}{*}{$\begin{array}{c}\text { Treating time } \\
\text { at } 900^{\circ} \mathrm{C} \\
(\mathrm{h})\end{array}$} & \multirow{2}{*}{$\begin{array}{l}\text { Starting Ti-foil } \\
\text { thickness } \\
(\mathrm{mm})\end{array}$} & \multicolumn{2}{|c|}{$\begin{array}{l}\text { Approximate composite } \\
\text { layer thickness }(\mathrm{mm})\end{array}$} & \multirow{2}{*}{$\begin{array}{l}\text { Volume fraction } \\
\text { of titanides layer }\end{array}$} & \multirow[t]{2}{*}{ Phases present } \\
\hline & & $\mathrm{Ti}$ & Titanides & & \\
\hline \multirow{3}{*}{0.5} & 0.15 & 0.122 & 0.078 & 39 & \multirow{3}{*}{$\begin{array}{c}\mathrm{TiCu}, \mathrm{TiCu}_{4} \\
\mathrm{Ti}_{2} \mathrm{Cu}_{3}, \mathrm{Ti}_{3} \mathrm{Cu}_{4} \\
\mathrm{Ti}_{2} \mathrm{Cu}\end{array}$} \\
\hline & 0.20 & 0.172 & 0.077 & 31 & \\
\hline & 0.25 & 0.225 & 0.074 & 25 & \\
\hline \multirow{3}{*}{5} & 0.15 & 0.083 & 0.118 & 59 & \multirow{3}{*}{$\mathrm{TiCu}, \mathrm{Ti}_{2} \mathrm{Cu}$} \\
\hline & 0.20 & 0.128 & 0.120 & 48 & \\
\hline & 0.25 & 0.181 & 0.119 & 40 & \\
\hline
\end{tabular}

\section{Results and discussion}

\subsection{Microstructure}

After processing, the composite microstructure consisted of alternating, well-bonded $\mathrm{Ti}$ and intermetallic layers. No unreacted $\mathrm{Cu}$ was detected in any of the processed composites. After 0.5 hour of treating at $900^{\circ} \mathrm{C}$, the intermetallic layers were composed of $\mathrm{TiCu}, \mathrm{TiCu}_{4}, \mathrm{Ti}_{2} \mathrm{Cu}_{3}$, and $\mathrm{Ti}_{3} \mathrm{Cu}_{4}$. When treating time was prolonged to 5 hours, the intermetallic layers were composed primarily of $\mathrm{TiCu}$. However, very thin layers of $\mathrm{Ti}_{2} \mathrm{Cu}$ were formed in both composites at the interface between the $\mathrm{Ti}$ layer and the $\mathrm{TiCu}$ phase (Fig. 1).

According to Colinet et al. [24], the formation of $\mathrm{TiCu}$ as the dominant phase is thermodynamically favoured and can be understood from the steps involved in another phases formation, which occurs through a series of the solid-liquid and the solid-state reac- 
Table 3. Summary of tensile properties of Ti-intermetallics laminated composites

\begin{tabular}{ccccc}
\hline $\begin{array}{c}\text { Treating time at } 900{ }^{\circ} \mathrm{C} \\
(\mathrm{h})\end{array}$ & $\begin{array}{c}\text { Starting Ti-foil thickness } \\
(\mathrm{mm})\end{array}$ & $\begin{array}{c}\text { Yield strength } \\
(\mathrm{MPa})\end{array}$ & $\begin{array}{c}\text { Ultimate tensile strength } \\
(\mathrm{MPa})\end{array}$ & $\begin{array}{c}\text { Strain at fracture } \\
(\%)\end{array}$ \\
\hline & 0.15 & 284 & 475 & 8.4 \\
0.5 & 0.20 & 250 & 427 & 10.6 \\
& 0.25 & 216 & 354 & 16.3 \\
\hline & 0.15 & 391 & 524 & 4.9 \\
& 0.20 & 312 & 451 & 6.5 \\
& 0.25 & 226 & 368 & 10.2 \\
\hline
\end{tabular}

tions. The Ti-intermetallics interface is characterised by the presence of a light-shaded reaction zone containing $\beta$-Ti and the Widmanstätten $\alpha-\beta$-Ti structure. The migration of copper atoms to titanium lattice lowers the eutectoid transformation temperature of titanium since copper is a strong $\beta$-stabilising element [25]. During cooling, $\alpha-\beta$-phase aggregate forms due to the decomposition of $\beta$-Ti. Detailed information concerning the structural changes throughout the time of formation of laminated titanium-copper titanide composites has been published previously [19]. Table 2 summarises the microstructural features of the Ti-intermetallics composites. The volume fraction of titanides was determined experimentally from image analysis.

\subsection{Mechanical behaviour}

The results of the microhardness measurements for $\mathrm{TiCu}, \mathrm{Ti}_{2} \mathrm{Cu}$, the mixture of phases $\left(\mathrm{TiCu}_{4}, \mathrm{Ti}_{2} \mathrm{Cu}_{3}\right.$ and $\mathrm{Ti}_{3} \mathrm{Cu}_{4}$ ), and $\mathrm{Ti}$ are $783,681,530$, and $273 \mathrm{HV}$, respectively. The titanide phases (especially $\mathrm{TiCu}$ ) give high hardness to the composite, while unreacted titanium provides ductility. Figure 2 shows the room-temperature tensile stress-strain curves for the laminated composites formed for 0.5 and 5 hours at $900^{\circ} \mathrm{C}$. Table 3 presents the room-temperature tensile behaviour of these composites.

The serrations in the stress-strain curves in Fig. 2 in the region beyond the yield point correspond to the formation of multiple cracks in the intermetallic layers after application of the tensile load. The failure and structure evolution in the course of straining of this composite has been investigated. At the early stage of plastic straining titanium grains of the composite were deformed by slip. Although Eroglu et al. [26] reported that the $\mathrm{Cu}$-Ti-base intermetallic phases have higher plasticity than other phases, no traces of plastic deformation were noticed in the intermetallic layers. Formation of cracks in the layers of intermetallic phases was the characteristic feature of the prolonged composite deformation. The light microscopy observations indicated that cracks propagated perpendicular to the intermetallic layers in composites that

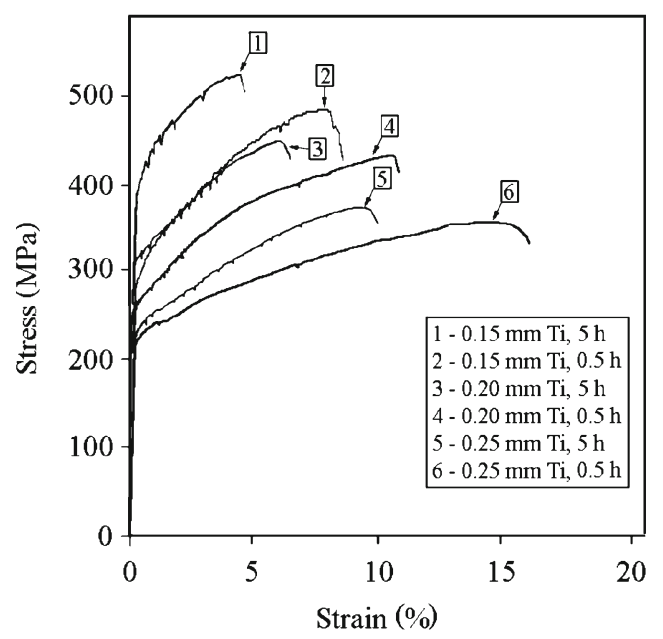

Fig. 2. Tensile stress-strain curves for the titanium-copper titanides laminated composites.

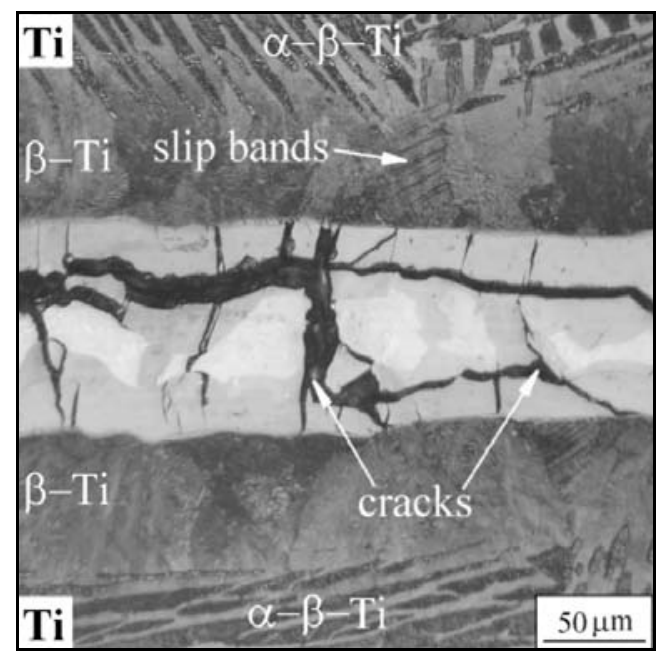

Fig. 3. Cracks in the specimen after 0.5 hour of treating at $900^{\circ} \mathrm{C}$ where testing was stopped prior to failure.

had been treated for 5 hours at $900^{\circ} \mathrm{C}$ (where titanide layers were composed primarily of $\mathrm{TiCu}$ ). The presence of cracks in the intermetallic layers running 

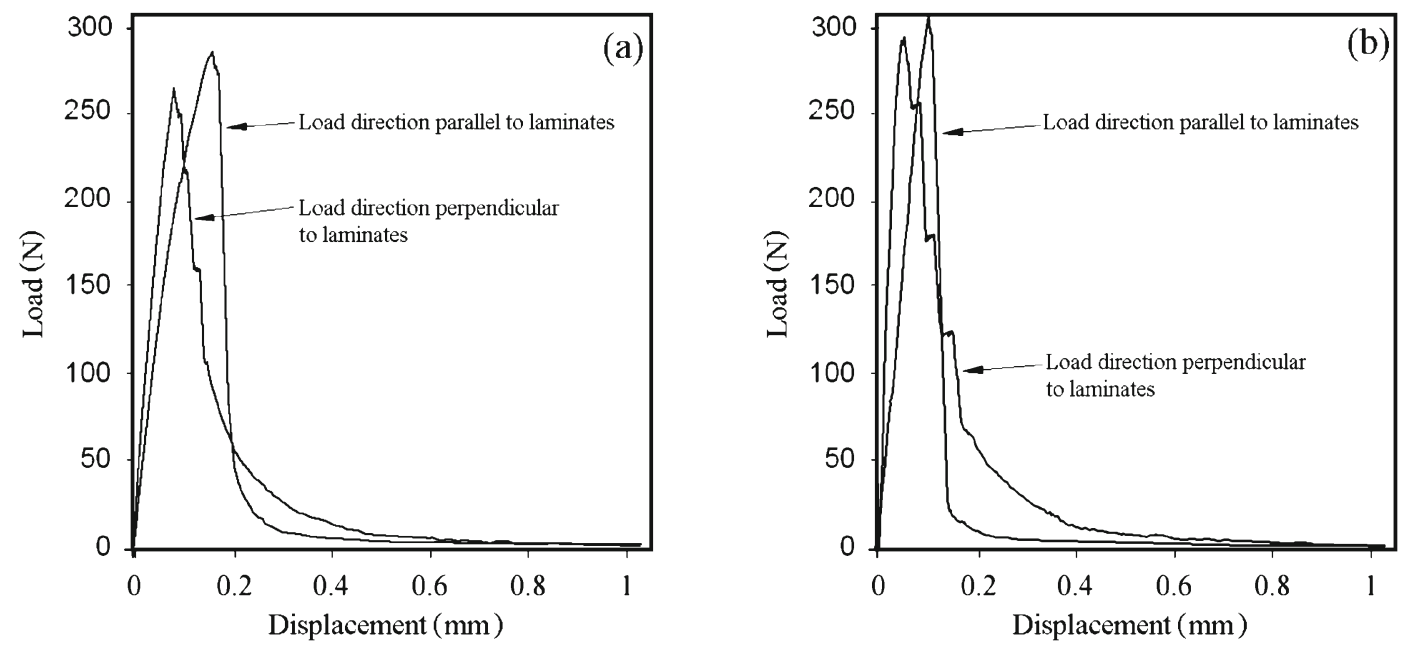

Fig. 4. Load-displacement curves of specimens at different load directions during a three-point bending test. Specimens formed using $0.15 \mathrm{~mm}$ Ti foil at $900^{\circ} \mathrm{C}$ for: (a) 0.5 and (b) 5 hours.

parallel and perpendicular to the metal layers was observed in composites after 0.5 hour of treating at $900^{\circ} \mathrm{C}$ (Fig. 3).

With permanent increase of the crack number in the layers of intermetallic phases the titanium layers gradually underwent the total external load. As a result, the plastic flow that took place in the titanium layers was restricted to the small regions between opposite cracks in the neighbouring layers of intermetallic phases. Thus a plastic strain of titanium was localised in shear bands. This behaviour is typical of ductile-phase-toughened composites [13, 20]. As shown in Table 2 , with an increase of the treating time at $900^{\circ} \mathrm{C}$, the intermetallic layers grow, leading to an increase in volume fraction of the intermetallics. As a result, the yield strength and the tensile strength of all investigated composites increase with increasing of the treating time and the total strain at fracture decreases after long heat treatment (Table 3 ). It should be added that the composites exhibit a good cohesion between titanium layers and layers of intermetallic phases during tensile test.

Figure 4 shows typical load-displacement curves of specimens formed at $900^{\circ} \mathrm{C}$ for 0.5 and 5 hours at different load directions during three-point bending test.

When the load perpendicular to the laminates was applied, the curve remained nearly linear up to the peak load, at which point a crack initiated from some surface defects giving the load drop. Such a crack travelled across titanium layer but did not travel across the specimen. It was arrested and deflected by the adjacent intermetallic layer of $\mathrm{Ti}_{2} \mathrm{Cu}$ causing delamination. Further loading caused transverse cracking of $\mathrm{TiCu}$ layer and formation of some new cracks in the next Ti layer (Fig. 5).

This process was repeated until all layers cracked, resulting in a step-like load-displacement response.
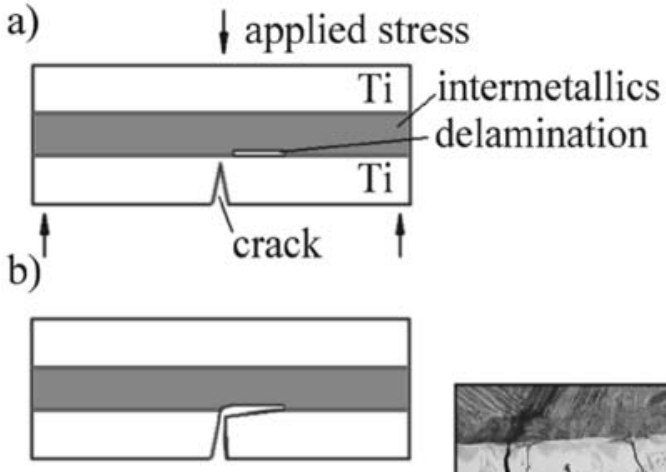

c)

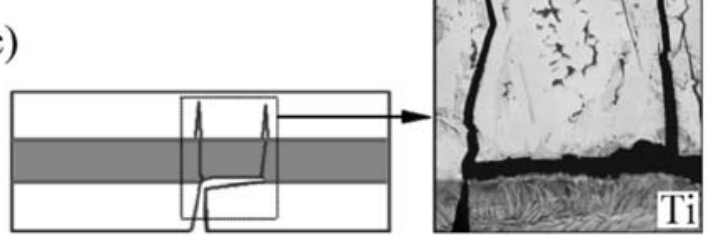

Fig. 5. Crack propagation in specimens loaded perpendicular to the layers.

This failure mechanism has been shown in the literature to be typical of laminated composites $[16,27]$. In many laminate systems, layer delamination can occur ahead of an advancing crack or as the result of a crack encountering an interface. This local delamination can result in crack deflection, which can significantly reduce the local stress intensity because of the large deviations in crack path (up to $90^{\circ}$ ). These crack path deviations cause the crack to move away from the plane experiencing maximum stress. Therefore, the crack deflection that occurs in the investigated composite is an effective means of reducing the driving force for crack growth. In addition, according to Lesuer et al. [28] increasing the length of crack deflection decreases the local stress intensity experienced by the 
Ta ble 4. The flexural strength of investigated composites under different testing conditions

\begin{tabular}{|c|c|c|c|}
\hline $\begin{array}{c}\text { Treating time at } 900^{\circ} \mathrm{C} \\
(\mathrm{h})\end{array}$ & $\begin{array}{l}\text { Starting Ti-foil thickness } \\
\qquad(\mathrm{mm})\end{array}$ & Load direction & $\begin{array}{l}\text { Flexural strength } \\
(\mathrm{MPa})\end{array}$ \\
\hline \multirow{3}{*}{0.5} & 0.15 & $\begin{array}{c}\text { parallel } \\
\text { perpendicular }\end{array}$ & $\begin{array}{l}273 \\
264\end{array}$ \\
\hline & 0.20 & $\begin{array}{c}\text { parallel } \\
\text { perpendicular }\end{array}$ & $\begin{array}{l}259 \\
234\end{array}$ \\
\hline & 0.25 & $\begin{array}{c}\text { parallel } \\
\text { perpendicular }\end{array}$ & $\begin{array}{l}246 \\
221\end{array}$ \\
\hline \multirow{3}{*}{5} & 0.15 & $\begin{array}{c}\text { parallel } \\
\text { perpendicular }\end{array}$ & $\begin{array}{l}311 \\
289\end{array}$ \\
\hline & 0.20 & $\begin{array}{c}\text { parallel } \\
\text { perpendicular }\end{array}$ & $\begin{array}{l}267 \\
248\end{array}$ \\
\hline & 0.25 & $\begin{array}{c}\text { parallel } \\
\text { perpendicular }\end{array}$ & $\begin{array}{l}258 \\
235\end{array}$ \\
\hline
\end{tabular}

crack tip. When the load direction was parallel to the laminates, the curve grew continuously up to the peak load, at which point a crack initiated at the surface. The failure that occurred by cleavage mode showed limited plastic deformation. Therefore, it is evident that there was solely one main crack. The crack grew gradually in the through-thickness direction and finally travelled across the specimen. Delamination was not observed when the load direction was parallel to the laminates. The flexural strength $\left(\sigma_{\mathrm{f}}\right)$ of the bended specimens was calculated from the maximum load $\left(F_{\max }\right)$ in the load-displacement curves according to:

$$
\sigma_{\mathrm{f}}=\frac{3 F_{\max } L}{2 W T^{2}},
$$

where $L$ is the supporting span of the three-point bending fixture, $W$ is the specimen width and $T$ is the specimen thickness. The flexural strength is listed in Table 4.

Results show that these composites exhibit anisotropy of mechanical properties during three-point bending test. The composites display superior flexural strength after 5 hours of treating time at $900^{\circ} \mathrm{C}$, especially, when the load parallel to the laminates is applied. The flexural strength increases with decreasing remaining Ti metal thickness in composites. These results are consistent with the work of Folsom et al. [29] pointing out that flexural strength of laminated composites depends on thickness of individual layers.

\section{Conclusions}

The MIL composites were successfully formed by reaction synthesis of $\mathrm{Ti}$ and $\mathrm{Cu}$ foils. The well-bonded and almost fully dense laminated structures can be designed and controlled easily. The microstructural characterisation indicated that $\mathrm{TiCu}$ is the predominant intermetallic phase. The formation of the $\mathrm{TiCu}$ phase is dependent on treating time at $900{ }^{\circ} \mathrm{C}$ and can be understood from the steps involved in another phases formation $\left(\mathrm{TiCu}_{4}, \mathrm{Ti}_{2} \mathrm{Cu}_{3}\right.$ and $\mathrm{Ti}_{3} \mathrm{Cu}_{4}$ ), which occurs through a series of the solid-liquid and the solid-state reactions. Independently on treating time, very thin layers of $\mathrm{Ti}_{2} \mathrm{Cu}$ are formed at the interfaces between $\mathrm{Ti}$ layers and the $\mathrm{TiCu}$ phase. The mechanical properties and fracture behaviour of the fabricated composites were examined. The results show that treating time at $900{ }^{\circ} \mathrm{C}$ is the main factor determining properties. After 5 hours of treating time all investigated composites have higher yield strength, higher ultimate tensile strength and higher flexural strength than composites after 0.5 hour of treating for the same starting thickness of Ti foil. Only strain at fracture of the composites decreases with increasing of the treating time. The results also show that the composites exhibit a good cohesion between titanium layers and layers of intermetallic phases during tensile test. Delamination of layers occurs during three-point bending test, especially when the load perpendicular to the laminates is applied. This local delamination results in crack deflection, which significantly reduces the local stress intensity and the driving force for crack growth.

\section{Acknowledgements}

Help from Dr. Renata Mola in SEM is greatly appreciated. 


\section{References}

[1] VECCHIO, K. S.: Pentagon Report, A118034, 2005.

[2] KIM, H. Y.-CHUNG, D. S.-HONG, S. H.: Mater. Sci. Eng., A396, 2005, p. 376.

[3] LI, T.-JIANG, F. C.-OLEVSKY, E. A.-VECCHIO, K. S.-MEYERS, M. A.: Mater. Sci. Eng., A 443, 2007, p. 1.

[4] XU, L.-CUI, Y. Y.-HAO, Y. L.-YANG, R.: Mater. Sci. Eng., A 435-436, 2006, p. 638.

[5] TIXIER-BONI, S.--VAN SWYGENHOVEN, H.: Thin Solid Films, 342, 1999, p. 188.

[6] EDELSTAIN, A. S.-EVERETT-RICHARDSON, G. R.-QADRI, S. B.- FOLEY, J. C.-PEREPEZKO, J. H.: J. Mater. Sci. Eng., A 195, 1995, p. 13.

[7] GACHON, J. C.-ROGACHEV, A. S.-GRIGORYAN, H. E.-ILLARIONOVA, E. V.-KUNTZ, J. J.KOVALEV, D. Y.-NOSYREV, A. N.-SACHKOVA, N. V.-TSYGANKOV, P. A.: Acta Mater., 53, 2005, p. 1225 .

[8] ALMAN, D. E.-HAWK, J. A.-PETTY, A. V.RAWERS, J. C.: JOM, 46, 1994, p. 31.

[9] ZHU, P.-LI, J. C. M.-LIU, C. T.: Mater. Sci. Eng., A $239-240,1997$, p. 532

[10] XIA, Z.-LIU, J.-ZHU, S.-ZHAO, Y.: J. Mater. Sci., 34, 1999, p. 3731.

[11] TAKUDA, H.-FUJIMOTO, H.-HATTA, N.: J. Mater. Sci., 33, 1998, p. 91.

[12] CAO, H.-LOFVANDER, J. P. A.-EVANS, A. G.ROWE, R. G.-SKELLY, D. W.: Mater. Sci. Eng., A 185,1994, p. 87.

[13] BLOYER, D. R.-VENKATESWARA RAO, K. T.RITCHIE, R. O.: Mater. Sci. Eng., A 239-240, 1997, p. 393.
[14] CHUNG, D. S.-ENOKI, M.-KISHI, T.: Sci. Technol. Adv. Mater., 3, 2002, p. 129.

[15] PENG, L. M.-WANG, J. H.-LI, H.-ZHAO, J. H.HE, L. H.: Scripta Mater., 52, 2005, p. 243.

[16] ADHARAPURAPU, R. R.-VECCHIO, K. S.-ROHATGI, A.-JIANG, F.: Metall. Mater. Trans., A 36, 2005, p. 3217.

[17] HARACH, D. J.-VECCHIO, K. S.: Metall. Mater. Trans., A 32, 2001, p. 1493.

[18] LI, T.-OLEVSKY, E. A.-MEYERS, M. A.: Mater. Sci. Eng., A 473, 2008, p. 49.

[19] KONIECZNY, M.: Mater. Lett., 62, 2008, p. 2600.

[20] ALMAN, D. E.-DOGAN, C. P.-HAWK, J. A.RAWERS, J. C.: Mat. Sci. Eng., A 192-193, 1995, p. 624.

[21] RAWERS, J. C.-PERRY, K.: J. Mat. Sci., 31, 1996, p. 3501.

[22] KONIECZNY, M.-DZIADOŃ, A.: Mater. Sci. Eng., A 460-461, 2007, p. 238.

[23] KONIECZNY, M.: Kovove Mater., 45, 2007, p. 313.

[24] COLINET, C.-PASTUREL, A.-BUSCHOW, K. H. J.: J. Alloy Compd., 247, 1997, p. 15.

[25] KUNDU, S.-CHATTERJEE, S.-OLSON, D.MISHRA, B.: Mater. Trans., A 38, 2007, p. 2053.

[26] EROGLU, M.-KHAN, T. I.-ORHAN, N.: Mater. Sci. Technol., 18, 2002, p. 68.

[27] ODETTE, G. R.-CHAO, B. L.-SHECKHERD, J. W.-LUCAS, G. E.: Acta Metall. Mater., 40, 1992, p. 2381.

[28] LESUER, D. R.-SYN, C. K.-SHERBY, O. D.WADSWORTH, J.-LEWANDOWSKI, J. J.HUNT, W. H.: Int. Mater. Rev., 41, 1996, p. 169.

[29] FOLSOM, C. A.-ZOK, F. W.-LANGE, F. F.: J. Am. Ceram. Soc., 77, 1994, p. 689. 